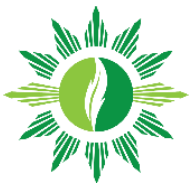

\title{
Covid-19 Pandemic Impact on World Economy
}

\author{
Zunaira Zahoor ${ }^{1^{*}}$ \\ 1Departement of Economics, Minhaj University, Pakistan \\ *Correspondence: zunairazahoor19@gmail.com
}

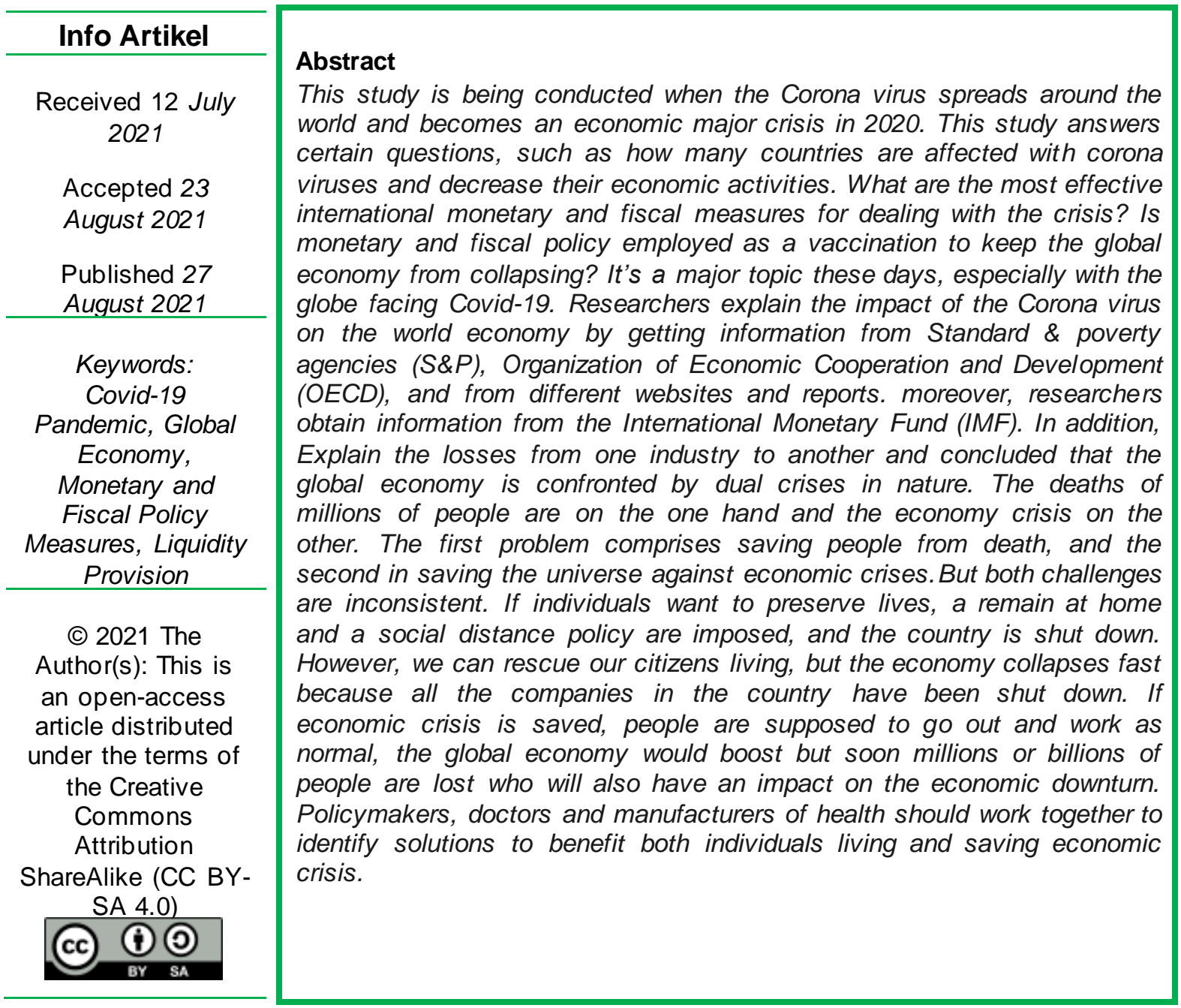

\section{Introduction}

A virus named Severe Acute Respiratory Syndrome (SARS-CoV-2) causes a Corona virus at the end of 2019. The occurrence of this respiratory infection was first exposed in Wuhan city of China. Dr. Li was the first person in the early days of his outbreak to detect corona virus epidemic. During his investigation, he realizes 
that there is a virus such as SARS that was a global 2003 epidemic. Corona viruses originated in Hunan marketplace for seafood, and victims were hospitalized with quarantine.

Dr. Li sends messages to his fellow medical practitioners, but after three days, Wuhan police urge Dr. Li to stop spreading such misinformation. Later, Dr. Li contracted the Corona virus from one of his patients and died because of it. Later on, Chinese health officials reported the ground facts of this Corona virus, its symptoms, and precautions. It is vital to note that Wuhan is a Chinese mid-city, and the Corona virus begins with China's spring festival. During this event, all Chinese people return to their hometown to see their parents, friends, and relatives and to celebrate the spring festival with their loved ones by eating and dancing.

This is the busiest times travel season in China. Prior to the Chinese government's formal statement, millions of individuals passed through Wuhan and became infected with the Corona virus. This is one of the main reasons the Corona virus spread so swiftly, with millions of people infected within a day. This rapid spread aroused grave consciousness at the national and global levels, and within weeks, it was recognized as an epidemic by the World Health Organization (WHO, 2021 ) in Wuhan, and rapidly dispersing in 200 countries worldwide. According to World master info at present on 10 June 2021, total numbers of Corona cases is $175,232,818$, out of these $3,778,635$ death cases and recovered case are $158,762,858$.

Globalization has resulted in incorporating all countries around the world. If something happens in one region of the world, it will have a medium or high impact on the economies of the rest of the world. The world's major economies, particularly China, have a significant impact on the rest of the world's economies. China has the world's second largest economy. It is valued at $\$ 13.6$ trillion. China contributes approximately $16 \%$ of the global GDP. It is the world's largest exporter. Most of the world's largest corporations rely on China for backward and forward connectivity. Because of the Epidemic Corona virus in China, most factories have shuttered, affecting the global economy.

According to(Bentolila et al., 2018; Morana \& Bagliano, 2010) several literatures have been found on the causes of world economy recession becau se of corona virus in huge amount. However, the world recession 2020, which is called a recession due to (covid-19) is new in the modern history. According to (Radelet \& Sachs, 1998) the 1997 Asian debt crisis was caused by a decline in the Thai baht, which created fear and prompted an economic slump and financial crisis in Asia.

Furthermore, in 2008 financial crisis was caused by a fragile monetary policy, a free regulatory system, and significant leverage in the banking sector, according to (Allen \& Carletti, 2010). In Nigeria, the recession in 2016 was caused by a balance-of-payments imbalance, and crude oil prices fell to their nadir. However, in this exploratory study, we will analyze how the Corona virus affects various economies around the world.

A number of confirmed cases of corona virus out of which death cases, and recovered cases on all over the world on the can be checked from the (Worldmeter, 2021). 
Table 1 The number of confirmed cases, death cases and recovered cases. Of the few countries

\begin{tabular}{llll}
\hline Countries & \multicolumn{1}{c}{$\begin{array}{c}\text { Confirmed } \\
\text { Cases }\end{array}$} & Confirmed Death & Recovered Cases \\
\hline World & $175,232,818$ & $3,778,635$ & $159,059,327$ \\
\hline USA & $34,264,727$ & 613,494 & $28,254,091$ \\
\hline Spain & $3,715,454$ & $3,715,454$ & $3,501,083$ \\
\hline Italy & $4,237,790$ & 126,767 & $3,936,088$ \\
\hline France & $5,725,492$ & 110,202 & $5,458,349$ \\
\hline Germany & $3,715,870$ & 90,187 & $3,563,800$ \\
\hline China & 91,337 & 4,636 & 86,285 \\
\hline UK & $4,535,754$ & 127,860 & $4,281,627$ \\
\hline Turkey & $5,306,690$ & 48,428 & $5,179,833$ \\
\hline Afghanistan & 85,892 & 3,356 & 59,871 \\
\hline Pakistan & 937,434 & 21,529 & 871,669 \\
\hline
\end{tabular}

Source: World meter statistics 10 June 2021

Tabel 2. According to World Health Organization (2021) on territory basis or region basis America has the highest numbers of Corona cases as compared to other regions

\begin{tabular}{lllll}
\hline Territory/Region & Confirmed case & New case & Total death & $\begin{array}{l}\text { New } \\
\text { death }\end{array}$ \\
\hline Western Pacific Region & $3,206,476$ & 17,321 & 48,902 & 343 \\
\hline European & $54,770,591$ & 46,451 & $1,161,608$ & 1,400 \\
\hline South East Asian & $33,101,517$ & 113,472 & 439,694 & 6,551 \\
\hline Eastern Mediterranean & $10,384,040$ & 30,704 & 207,111 & 538 \\
\hline America & $68,932,684$ & 152,822 & $1,810,788$ & 5,090 \\
\hline African & $3,593,021$ & 12,199 & 88,831 & 246 \\
\hline Total (global) & $173,989,093$ & 372,822 & $3,756,947$ & 14,169 \\
\hline
\end{tabular}

Source: World Health Organization (WHO)

\section{Literature Review}

Initially, it was predicted that the corona virus (covid-19) pandemic would be limited to China. However, because of the movement of people, the corona virus has spread worldwide, with over 200 countries being affected by it. As a preventive move, the World Health Organization has declared that the Corona virus is spreading over the world and is easily transmitted from person to person. Everyone should keep their distance from one another. They also stated that staying at home was vital to avoid the corona virus.

Every country on the globe took precautionary measures to protect themselves from the Corona virus, which has caused the entire world to be shut down. Instead of some fundamental good generating factories, the entire world's industries lock down. According to(Elliott, 2020; Horowitz, 2020) all countries are detached from one another, which has a negative impact on the aviation business. Along with the cancellation of major sporting events such as the PSL (Pakistan Super League), the sports sector suffers. 
According to Covid-19, the 2020 crisis will be not only devastating, but will also have a spillover effect on the global economy due to supply and demand shocks in every area of businesses (El-Erian, 2020).

According to the US Federal Reserve's monetary policy report, the size of the Chinese economy will have a significant impact on the global economy and the US. China's total GDP contribution to the global economy is 13.6 percent, the second biggest after the US economy, which contributes 16.8 percent. Some economists predict that the world's developed economies' GDP would increase less in 20222021 than it did in 2019. It is up to the government to decide how to deal with Covid-19. According to John Detrixhe, the world's GDP prediction table is shown below.

Table 3 The world's GDP Prediction's

\begin{tabular}{llll}
\hline \multicolumn{4}{c}{ Forecast for percentage Change in GDP } \\
\hline Countries & $\mathbf{2 0 1 9}$ & $\mathbf{2 0 2 0}$ to 2021 GDP & Change \% \\
\hline World & 2.9 & 2.5 & -0.5 \\
\hline USA & 2.3 & 1.9 & -0.4 \\
\hline UK & 1.4 & 0.8 & -0.6 \\
\hline China & 1.4 & 0.8 & -0.6 \\
\hline Euro Countries & 1.2 & 0.8 & -0.4 \\
\hline South Korea & 2.0 & 2.0 & 0 \\
\hline South Africa & 0.3 & 0.6 & 0.3 \\
\hline
\end{tabular}

Source: John Detrixhe forecast for percentage change in GDP

According to above table it has been shown that world's GDP is falling down from 2.9 in 2019 to 2.5 in 2020-2021. Which shows that decrease in the world GDP with negative 0.5. International monetary fund (IMF) managing director (Tao Zhang) said currently world economy in front of three biggest challenges, which contain tension on trade front, financial and fiscal risk, how to achieve inclusive growth. He believed global economy sun is still shining. But world largest econ omy US and China have trade war, diverse models try to access both economy impact on probable trade war, and to mitigate the possible effective measures. But condition truth is much complex than predicted model. Difference or disagreements at all essential points need to resolve with cooperative approach. If not, then trade tension would consequence in global economy losses. Zhang says about fin ancial or fiscal risk, he elaborated that total world debt was recorded \$164 trillion in 2016. But currently in 2021 crisis, it is superior to the level seen in 2008 crisis. Countries must awake of their fiscal conditions and maintain economic growth. Some countries approach like fully employment, government expenditures will definitely reduce the risk to sustainability. Economies should focus on innovative ideas and there is a potential for financial technology and implement these ideas to bring efficiency gain.

The rapid increase the virus in China, shows that over 3000 death and over 80 thousand infected people of the world's 2nd largest economy implicit to lockdown the domestic and international travel. Which result in declining the economy of China and ultimately affects the world economy? According to S\&P rating agency, China shows that $20 \%$ of worldwide manufacturing output in 2018 , which is now expected to decline approximately from $5 \%$ to 
$5.7 \%$ because of an outbreak of coronavirus. Government of China injected 1.2tn Yuan into a financial market by reducing the rate of interest to support the economy. Further, China also reduced the tariff by halves on US goods, and taxes also reduced by $5 \%$ instead of $10 \%$, now it reduced more from $2.5 \%$ instead of $5 \%$. Fed notice Asian economies will affect because of Corona virus spread. According to head of European central bank (Lagarde, 2021) Virus intimidation is a novel risk to economic stance, replacing China-US trade war.

\section{Result and Discussion}

\subsection{Impact on the tourism industry}

The Corona virus is spread over 200 countries. The situation is panic in the entire world. Government of all countries restrict their people to unnecessary travel, domestic or internationally. Mostly countries suspended tou rist visa, residential visa and work visa. If we take an example of Kingdom of Saudi Arabia (KSA) which is Holy Country for all Muslim world.

Every year millions of people visit Makah (city of Saudi Arabia) to perform Hajj, which is one pillar of Islam. As per the government statistics of KSA, in 2019 before corona approximately 2.5 million Muslim around the world visit for Hajj prayer. But during corona KSA announced to stop Hajj application to prevent people from (covid-19). Same as other countries wholly prohibited inbound and outbound travel. Government forced travel restriction impact on numbers of passenger decreases in the entire world. With a reduction of number of passengers, some airlines stopped their operations, such as polish airline, Baltic airline. These travel restrictions will affect the tourism industry worldwide and approximately $\$ 200$ billion losses foreseeable. Aviation industry losses cross the figure of $113 \$$ billion by IATA estimation. American Airlines Seeks $\$ 50$ Billion Compensation.

According to World Travel and Tourism Council (WTTC) mention that because of corona virus pandemic situation over 50 million jobs cut down in travel industry. Tourism industry contributes $10 \%$ for Global GDP. After the epidemic of corona virus tourism industry needs 10 months for revival of tourism industry. Further WTTC said that Asia is mainly affected continent.

According to Virginia Messina (WTTC Managing Director) said policies are general and not verified to be effectual to hold the virus. She further said tourism restriction could also affect not only to medical supplies delivery but also on medical expert's travel. Messina said every month over 850,000 citizens take a trip from Europe to USA. This is comparable to $\$ 3.4$ billion monthly payment to US economy. She said out of 50 million employments lost, near about 30 million is from Asia, 7 million from Europe, 5 million from Americas and other territories.

WTTC recommends countries should make trouble-free policies regarding visa process, and trim down the taxes on traveling and start incentives later than the epidemic situation.

\subsection{Impact of corona virus on global hospitality industry}

Hospitality industry affected because of corona virus epidemic situation. Various country's government announced the slogan "social distancing" and "Stay at home" lead to shut down the restaurant, parks, cafes, hotels, to prevent the 
spread of covid-19. Hotels from all around the world witnessed booking termination value billions of dollars, and the hotel industry bailout $\$ 150 \mathrm{bn}$. Executives of Restaurant and hotel industry lost their jobs and trying to find a new job.

According to Smith travel research (STR) weekly reports show that metrics are ongoing to catch worse because of pandemic Covid-19. This information based on 9.2 million rooms and 68000 properties around the globe. Reports show that in comparisons to last year 2019, tenancy is extremely down approx. 95\% in Italy, $67 \%$ in UK, 68\% in China, 59\% down in USA, and in Singapore its down level is $48 \%$. As we know China is an earliest market to deal with corona virus and luckily successfully defeat the Corona virus and now hospitality industry in China is forwarding to stabilization. Now $87 \%$ hotels are opened in whole China, which was only $40 \%$ in past 2 months. Tenancy is turned to positively. In May it was $10 \%$, at the end of June it increased up to $22 \%$ and beginning of July it proximately increases to $30 \%$. But if we talk about the world, still there is worse condition in hospitality industry until they stop covid-19. In USA still tenancy is $30 \%$, which is not a good signal.

The Tenancy in US hotel industry did not fall down quickly as compared to other countries like China, Italy; the reason is US government did not announce lock down policy. Still people traveling in USA, and not practice the social and physical distancing. That's the reason corona virus infection rate is much high in USA as compared to other countries.

According to Revenue per available room (Rev.PAR) performance measure in hospitality industry, shows statistics that now the hospitality industry falls down more than compared to financial crisis of 2008, and terror attack on 11 September. In China Rev.PAR, declines up to $85 \%$, while in Europe it drops $69.5 \%$, and in US it drops up to $44 \%$.

According to STR, Rev.PAR breaks the record of declining of last 30 years. Cumulative data of top 25 markets in USA shows major declining, aggregate occupancy down over $66 \%$ to $26 \%$.and Rev.PAR down from $80 \%$ to $27 \%$. STR declared about the collapsed of occupancy in his report. According to Jasper Palmqvist STR area director predict the recovery phase hoping it almost takes 6 months for $v$ shaped recovery which also seen in SARS crisis.

\subsection{Impact of Corona virus on the global sports industry}

The impact of corona virus on sports industry is very high. According to sports global value analysis, currently sports market contributes annually US $\$ 756 \mathrm{bn}$, which includes US $\$ 420$ bn by USA and remaining by Europe accounted US $\$ 250 \mathrm{bn}$. Below this China is the most growing sports industry which makes US4 150billion annually. If we see all major sports events in the world from athletes, leagues, teams, media and broadcast stopped or delayed because of pandemic covid-19.

Football leagues in Scotland and England announced to instantaneous postponement of football matches. In USA National Basketball Association (NBA) paused their season and Revenue lost amount is 350 million to 450 million US dollar. The world's biggest sports event is Olympic Games, which is planned in Japan Tokyo at the end of July 2021, but because of corona virus International Olympic Committee (IOC) delayed this event till 2021. Now it starts from 23 July to 
$8^{\text {th }}$ of august in 2021 . Japan suffers a loss approx. 597 billion yen which it already invested to host this sports event.

Marathon's race was listed to get put on $26^{\text {th }}$ April also postponed until October. World Athletics championship planned to organize on August 2021. But now it is delayed in July 2022, to avoid contradictory with the diary of Olympic Games. Formula one also stopped their events because of corona virus. In Portugal government stated emergency in the countryside and Motorsport's game occasion and other events postponed.

World snooker championship also postponed. A cricket league in Pakistan PSL (Pakistan Super league) postponed because of corona virus. In golf sector, LPGA rescheduled its event and resulting billions of dollars Revenue loss. According to (SimonDenyer), chief executive of television and internet sports streaming said, in 75 years it is a biggest disaster in sports industry.

\subsection{Impact of Corona virus on global Education industry}

According to United Nations Educational, Scientific and Cultural Organization (UNESCO), around 290 million students or learned affected because of corona virus covid-19. Mostly countries have temporarily closed their educational institutions to control the Corona virus from spread. It damages the education industry to $\$ 600$ billion. According to UNESCO observation, 188 countries have nationwide or complete closure their educational sectors. And 5 other countries closure educational institutions on local basis. Total impact is 99.4 percent of the world student's population.

Cambridge international Examinations have canceled all their examinations for all levels worldwide. Corona virus had severe impact on those schools wherever the lack of online education platform. A credit rating agency (Moody's) downgrades the USA education system which is an outburst from stable to downbeat. The reason is that over $30 \%$ universities and colleges in US have low operating performance. So it is difficult for these institutions to adapt academic and financial changes which are necessary to manage with corona virus. Italy and Spain Nigeria, France, Israel, and Egypt closure all their schools, while Australia closures some of their schools. This worse condition in educational sectors creates unemployment for most of the teachers.

Government of Netherland also temporary suspended all examinations for students. The positivity of this condition is it increases the value of online education and distance learning, but a tiny proportion of institution to provide online educations. In USA only $15 \%$ undergraduates who studied online classes and get degrees in 2019. Other countries like Canada, UK bear billions of dollars lost in education Revenue because foreign students suspend their studies and went back home. According to Deloitte report, because of cancellation of Federation of English language teaching organization (FELTOM) monthly financial loss is near about Euro 1.4 million, whereas Malta's economy cost is Euro 3.4 million per month.

\subsection{Impact of Corona virus in Health industry}

As other sectors, hospital sectors are on the front line to fight with corona virus pandemic. Hospital industry faces supply chain dispute and knocks to its revenue from the termination of elective surgeries. Mostly countries have increased 
the services with higher level of demand but if we talk about testing, equipment which are in greater numbers in private hospitals.

China has closed all its hospitals in Wuhan, while in Iran hospital are doing more struggles to fight with this corona virus. In Spain government nationalized all private hospitals and healthcare centers to fight with spreading of corona virus. Singapore has sufficient equipment and health facilities to control corona virus. Further Ministry of health $(\mathrm{MOH})$ in Singapore advised to all doctors in private and public sectors not to accept any foreigner patient.

Pharmaceutical industry suffers billions of dollar losses because supply chain affected of medicine companies. Major drug making companies import ingredient from Chinese companies. Approx. before the Corona outbreak, China produces the $60 \%$ ingredients of world pharmaceutical industry. After the outbreak of Corona virus, all pharmaceutical ingredients stopped because of multiple reasons. First, China had shut down its factories which make drugs. And second, there is a big supply chain problem; thirdly various countries canceled their contract to import these ingredients from China. The excessive dependence or trust on

Chinese manufacturer raises the considerable risk to the worldwide pharmaceutical industry, and outbreak of Covid-19 proved it. The rating agency S\& $\mathrm{P}$ shows that health industry fell down up to $7 \%$ at the start of March 2020 which shows that health investor felt industry hit severely. Moody's rating agency shows that cash flow is very low as compared to 2019.further he said nonprofit and public sectors of healthcare go downgraded from stable to negative cause of the Corona virus Covid-19.

\section{Policy Responses to Covid-19}

Different countries implemented different policies regarding monetary and fiscal policy, human Control policies, and health policies to sustain the econ omy of their countries. Over 200 countries affected with covid-19. Human control policies which are implemented by all affected countries include shutdown the airbase, sea border and land border. Some countries temporarily release the prisoner from overcrowded prison. Some countries nationwide closed all universities, colleges and schools to break the chain of virus.

Some countries impose "Curfew" in the whole country with slogan to stay at home. Countries suspended all tourist visas, residential visa for temporary time. Some countries ban to travel inside or outside the country. Public health policies include public quarantine, border quarantine, stay at home, social distancing. It is not possible to explain the Monetary and Fiscal Policy responses of all countries around the globe. Research randomly selects some developed and some developing countries, and explains their Policies against covid-19 situation. 
Table 4 The monetary and fiscal policies of some randomly selected companies.

\begin{tabular}{llll}
\hline Countries & Monetary Policy Measures & Fiscal Policy Measures \\
\hline USA & Lowered $150 \mathrm{bp}$ to $0-0.25 \mathrm{bp}, \$ 2.3$ trillion (11\% of GDP) relief for \\
& purchase treasury and agency corona aid, include 1 time tax rebate to \\
& securities, expand term repos, individual is US $\$ 250$ billion,
\end{tabular}

lower cost of lending discount, unemployment benefit US\$250 billion, reduce swap cost, temporary repo food safety US $\$ 24$ billion, provide loan, facility for foreign $n$ international guarantees to corporate bankruptcy monetary, federal reserve support prevent US\$510 billion, SME loan facility flow of credit, which US\$359 billion to keep worker, hospital include primary dealer credit US4100 billion, state $n$ local facility, mutual market liquidity government US\$150 billion, corona facility, corporate credit facility, virus preparedness at response asset back security loan, US $\$ 8.3$ billion, families first response at paycheck protection liquidity US\$83.4 billion,

facility, street lending program, municipal liquidity facility,

UK Monetary measure includes, UK fiscal measure includes, £5.7 billion decrease bank rate by 65 bps, for charities and public services, £27 expand the UK government bond billion for business support, means which hold by central banks and property tax holidays, grant for most also expand the £200 billion of affected sectors, sick pay leave non-financial corporate bonds. compensation, £7 billion for social Planned new funding scheme to safety for people, introduce corona reinforce the rate cut. More virus interruption for business loan incentives for lending to real scheme with the help of British estate economy. Use of business bank and government, on government overdraft account large and small scale. For next quarter with BOE to provide liquidity. Joint deferred VAT payments, provide $80 \%$ BOE and HM treasury for earning of self-employed, which is corporate financial facility with $£ 2500$, is given for initial three months. business loan scheme to give $£ 150$ million to IMF for catastrophe loan and guarantees of $£ 330$ relief trust.

billion. Activate repo for liquidity

facility. Lower UK countercyclical

rate to $0 \%$.

Pakistan State bank of Pakistan (SBP) cut PKR 1.2 trillion relief package the policy rate from 225bps to announced by authorities. Remove the $11.0 \%$. Introduce two refinancing import duties on health equipment. facilities. One is (TERF) PKR 200 billion for daily wages worker, temporary economic refinancing PKR 150 billion allocated to lowfacility with worth of PKR 100 income families cash support, PKR 100 billion to invest in buying latest billion for export industry to relief from manufacturing equipment and tax refund. PKR 100 billion support to plants at 7\% fixed for next 10 SMEs, PKR 280 billion for wheat years. Secondly (RFCC) procurement resources, PKR 50 billion refinance facility for for utility stores,

combating covid-19, SPB took PKR 70 billion for fuel prices, PKR 50 some other measure to sustain billion for food and health equipment, economic activities. Reduce PKR 110 billion relief on electricity bill capital conservation from 100bps payment. PKR 25 billion for NDMA to to $1.5 \%$, PKR 180 million for buy equipment for fight the covid-19. extension of credit to SMEs, 50 to 
$60 \%$ relaxation on debt ratio.

Spain

ECB provide monetary policy $13.9 \%$ (1\% GDP) key measures, support include buy asset ( $€ 120$ contingency budget support fund to billion) until last of 2020 with APP health ministry (€1 billion), region program, auction of full allotment, health services (€2.8 billion), research fixed rate, liquidity facility at funding for covid-19 vaccine and drug deposit facility rate, $€ 750$ billion ( $€ 110$ million), unemployment benefits for asset purchase for pandemic for worker laid off, increase 60 to $75 \%$ emergency, relaxation for euro sick pay for quarantined or infected system refinancing (MROs, workers, allowance self-employed LTROs, TLTROs), provide loans workers for suspension of activities, to SMEs, individual and subsidy for household employees up to household. ECB allowed $70 \%$, monthly allowance $€ 430$ to institution to operate below pillar 2 workers for expiring their contract guidance. Liquidity coverage during these emergency days, extra ratio, new rule on composition of budget fund is

capital, release countercyclical $€ 300$ million, $€ 25$ million for meal of capital buffer, relaxation for non- kids affected by school, landlord performing loan, $€ 100$ billion provide energy provision, $50 \%$ government loan for companies exemption for employer social security, and self-employed, €2 billion for deferral tax payment for

exporter, loan maturity extension SME amount ( $€ 14$ billion)

for farmers, $€ 83$ billion leverage to

help private sector, $€ 10$ billion for

other institutions funding, $€ 400$

million 3-month mortgage

payment.

Italy $\quad$ ECB provide monetary policy Government adopted $€ 25$ billion (1.4\% support include buy asset (€120 of

billion) until last of 2020 with APP GDP), for emergency package. (€3.2 program, auction of full allotment, billion) Fund to strengthen Italian health fixed rate, liquidity facility at system, $€ 10.3$ billion to preserve job deposit facility rate, $€ 750$ billion and help income laid-off worker, $€ 6.4$ for asset purchase for pandemic billion for deferral tax and emergency, relaxation for euro postponement of utility bills payment, system refinancing (MROs, $€ 5.1$ billion for supply of credit, LTROs, TLTROs), provide loans $€ 400$ billion (25\% of GDP) for liquidity to SMEs, individual and decree for state guarantees, $€ 750$ household. ECB allowed billion liquidity for household and institution to operate below pillar 2 business.

guidance. Liquidity coverage ratio, new rule on composition of capital, release countercyclical capital buffer, relaxation for nonperforming loan, $€ 100$ billion government loan for companies and self-employed, $€ 2$ billion for exporter, loan maturity extension for farmers, $€ 83$ billion leverage to help private sector, $€ 10$ billion for other institutions funding, $€ 400$ million 3 month mortgage payment. 
France

ECB provide monetary policy Authorities announced $€ 100$ billion support include buy asset ( $€ 120$ more than (4\% of GDP), to fight with billion) until last of 2020 with APP corona virus, include liquidity measure, program, auction of full allotment, include more $€ 45$ billion in annual fixed rate, liquidity facility at budget which is expected to introduce deposit facility rate, $€ 750$ billion 13 April to 17 april,2020, $€ 312$ billion) for asset purchase for pandemic for guarantees of bank loan and credit emergency, relaxation for euro reinsurance, which include boosting system refinancing (MROs, health insurance for caregiver or sick, LTROs, TLTROs), provide loans rise in the health spending, postponed to SMEs, individual and for tax payment for firms, liquidity household. ECB allowed support for social security, support institution to operate below pillar 2 worker wager under reduced hours guidance. Liquidity coverage schedule, financial help for small ratio, new rule on composition of enterprises, individual worker and capital, release countercyclical professional, postpone for utility bills capital buffer, relaxation for non- and rent for small business, grant performing loan, $€ 100$ billion exceptional bonuses, extend the government loan for companies unemployment benefits expiration and self-employed, €2 billion for during this emergency

exporter, loan maturity extension for farmers, €83 billion leverage to help private sector, $€ 10$ billion for other institutions funding, $€ 400$ million 3-month mortgage payment. Decrease the counter cyclical bank capital buffer to $0 \%$, which was increased from $0.25 \%$ to $0.5 \%$ which is effective from April. Fully banned on sale of short stock till April.

Germany ECB monetary policy support Federal government adopted additional $+\quad$ budget $€ 156$ billion, (4.9\% of GDP), release counter cyclical capital include $R \& D$ vaccine for covid-19, buffer from 0.25 to $0 \%$, further health care supplies and equipment, $€ 100$ billion short-term worker access, subsidy to refinance for SME to short term preserve jobs and workers income, liquidity, financial stabilization increase childcare benefits for low$€ 100$ billion for companies to income parents, support of selfstrengthen capital positions, $\quad$ employed with income benefits, $€ 50$ billion grant for small enterprises and infected patients, tax free deferral for this year, create economic stabilization fund and KFW bank, increase the access and volume to provide loans for all firm sizes. $€ 757$ billion for increase the volume, $€ 48$ billion for direct support and $€ 63$ billion for state level guarantees loans.

Turkey CBRT decreases the policy rate Turkey announced TL100 billion from $100 \mathrm{bps}$ to $9.75 \%$ provide packages to support his economy. liquidity facilities, provide an Which include TL75 billion or $\$ 11.6$ instrument for longer term at billion (1.5\% of GDP) used for fiscal 


\begin{tabular}{|c|c|}
\hline & $\begin{array}{l}\text { discounted rate. Requirement for measure. Other TL25 or } \$ 3.8 \text { billion } \\
\text { reserve of foreign currency }(0.5 \% \text { of GDP) used to increase the } \\
\text { decrease by 500bps. Facility for credit funds. Some other measures } \\
\text { exporter and SMEs. Maturities for include increase pension of fund, and } \\
\text { exporter inventory extend and provide cash to needy families. } \\
\text { give discount credit. Limit of LTV Employment protection with the help of } \\
\text { on mortgages increase from } 80 \text { to short-term work allowance rules. } \\
90 \% \text { Provide } 3 \text {-month Postpone or reduced taxes for different } \\
\text { moratorium for repayment of bank sectors industries which major affected } \\
\text { loans. Companies' bankruptcy by covid-19. Support Turkish airline. } \\
\text { has been suspended } \\
\text { Increase the extension of personal, } \\
\text { corporate incometax. }\end{array}$ \\
\hline China & $\begin{array}{l}\text { Monetary measure includes, RMB } 2.6 \text { trillion }(2.5 \% \text { of } \text { GDP) } \\
\text { decrease bank rate by } 65 \text { bps, financing plan announced by China, } \\
\text { expand the UK government bond out of } 2.5 \text { GDP, } 1.2 \% \text { of GDP } \\
\text { which hold by central banks and implemented in first quarter of } 2020 \text {, } \\
\text { also expand the pound } 200 \text { billion which include increase the amount on } \\
\text { of non-financial corporate bonds. prevention and control from covid-19, } \\
\text { Planned new funding scheme to to expand medical equipment } \\
\text { reinforce the rate cut. More production, accelerate unemployment } \\
\text { incentives for lending to real insurance disbursement, relief from } \\
\text { estate economy. Use of taxes and social security payment, } \\
\text { government overdraft account expand overall fiscal measures. health } \\
\text { with BOE to provide liquidity. Joint Improvement in public hem hem } \\
\text { BOE and HM treasury for management system for emergency } \\
\text { corporate financial facility with } \\
\text { business loan scheme to give } \\
\text { loan and guarantees of pound } \\
330 \text { billion. Activate repo for } \\
\text { liquidity facility. Lower UK } \\
\text { countercyclical rate to } 0 \% \text {. }\end{array}$ \\
\hline Afghanistan & $\begin{array}{l}\text { Financial stability committee } 1.9 \text { billion (0.1\% GDP) budget for health } \\
\text { monitoring risk regarding emergency, testing lab, medical } \\
\text { monetary and showed to bank to supplies, } 57 \% \text { rise (0.55\%GDP), social } \\
\text { provide liquidity. } \\
\text { uninterrupted financial services, down nonessential spending, get } \\
\text { enhanced foreign currency finance from World bank, Asian } \\
\text { transaction and remote services development bank, Islamic } \\
\text { which are closure. }\end{array}$ \\
\hline
\end{tabular}

The world affected the corona virus pandemic took some policy measure regarding monetary policy, fiscal policy, human control policy and healthcare policies. There are some issues regarding these measures due to which these measures cannot stop the recession. First, if we talk about the monetary policy in which central bank, International monetary fund reduces the rate of interest, to increase the supply of money in market. But on the other side demand for money is not high, people are staying at home, all business shut down. Business executive not interested to take a loan even at low interest rate.

There is a slogan stay at home and social distancing stopped people to go outside and buy anything. If no customer or consumer then there is no business, if no business then no need of capital to invest. Now situation is, banks are ready to 
give loan, but cannot find an investor to take this loan at low interest rate. So, this monetary policy step is not beneficial for global economy.

Mostly economist said that monetary policy is not a vaccine to stop recession. Various countries took different monetary policies to increase the economic activities. But to save people's life government also imposed stay at home and social distancing. Which result a fear in the mind of people, and all economic agents are powerless to interact with each other regarding economic activities.

Covid-19 is now a big political issue in most of the countries regarding fiscal policy. It is difficult for government to take some fiscal measures, like which sector are more deserving for packages and which sectors are less important. Currently, it is a big debatable issue in developed and underdeveloped economies like USA and UK. Now every sector of the industry trying to get more packages from government to keep sustain from this covid-19.

Some big businesses argue that government is giving more packages to banking industry, education industry, health industry, manufacturing industry as compared to entertainment industry, hospitality industry. They protested against government and saying why government did not consider other sectors like entertainment and hospitality industry significant contributor to the economy

\section{Conclusion}

Entire world is suffering covid-19 and the policy maker in central bank and other biggest institution who introduce new policies to ease the global economy are at high pressure. Previous crisis in 2008 is just a challenge to fight with financial crisis. But currently covid-19 crisis is dual nature. First to save the people, second is to save the economy. Each measure is difficult to achieve because if we choose to save the people means took measure like to stay at home, social distancing, shut down the country to protect our people from death, it is ultimately we cannot save the economy globally. Because all businesses shut down, from lower wages worker to executives suffer from this shut down and economy falls down quickly. But on the other side if we save economy then government needs to ignore the precautionary measure from covid-19, everything is going as usual. No shutdown in the countries. No social distancing and stay at home. With this second step maybe, our economy will go up but we cannot save the lives of people, it is expected millions of people died if they infected with this corona virus. If we see in the long term, millions of people to death will also directly affect the fall of economy. But if we save our people, it is chance we can boost our economy near future. There is a big challenge for policy maker to take such measure which not only save the people but also save the economy. This is a time to work together. All policies failed if there are no health precautionary measures. Doctors, economist, policy maker should sit together and implement those measures which have dual effect like it not only save people but also save economy.

\section{References}

Allen, F., \& Carletti, E. (2010). An Overview of the Crisis: Causes, Consequences, and Solutions*. International Review of Finance, 10(1), 1-26. https://doi.org/10.1111/j.1468-2443.2009.01103.x 
Bentolila, S., Jansen, M., \& Jiménez, G. (2018). When Credit Dries Up: Job Losses in the Great Recession. Journal of the European Economic Association, 16(3), 650-695.

El-Erian, M. A. (2020, August 18). The Coming Coronavirus Recession. https://www.foreignaffairs.com/articles/2020-03-17/coming-coronavirusrecession

Elliott, L. (2020, March 15). Prepare for the coronavirus global recession. The Guardian. http://www.theguardian.com/business/2020/mar/15/prepare-for-thecoronavirus-global-recession

Horowitz. (2020). The global coronavirus recession is beginning. https://www.cnn.com/2020/03/16/economy/global-recessioncoronavirus/index.html

Lagarde, C. (2019, September 23). The trade war is weighing "like a big, dark cloud" on the global economy, says. https://www.cnbc.com/2019/09/23/lagarde-trade-is-the-biggest-hurdle-for-theglobal-economy.html

Morana, C., \& Bagliano, F. (2010). The Great Recession: US Dynamics and Spillovers to the World Economy. Journal of Banking \& Finance, 36. https://doi.org/10.2139/ssrn.1709955

Radelet, S., \& Sachs, J. (1998). The Onset of the East Asian Financial Crisis (NBER Working Paper No. 6680). National Bureau of Economic Research, Inc. https://econpapers.repec.org/paper/nbrnberwo/6680.htm

WHO. (2021). WHO Coronavirus (COVID-19) Dashboard. https://covid19.who.int

Worldmeter.(2021).Countries where Coronavirus has spread. https://www.worldometers.info/coronavirus/countries-where-coronavirus-hasspread/ 